\title{
Invasive non-native species of fish in upper Paraná river Basin, Brazil: variations of caloric content in Cichla kelberi
}

\author{
Luis Alberto Espínola ${ }^{1}$, Horácio Ferreira Júlio Junior ${ }^{2}$ and Evanilde Benedito²
}

The allocation of assimilated energy may be influenced by seasonal changes, growth, and reproductive cycle of fish, food consumption and environmental conditions. The objective of this research was to evaluate the energetic variations of Cichla kelberi in the upper Paraná River floodplain, analyzing the caloric content in muscles, gonadosomatic index (GSI), and the condition factor between assessed systems, sex, and stage of gonadal maturation. The results obtained in the present study permit assuring that this is a species that efficiently converts the resources of the environment into energy. Although presenting higher condition factor in the environment where there is a greater ease in getting food (Paraná subsystem), the energy identified in the muscles was the same in both subsystems. During the process of gonadal maturation there is optimization in energy accumulation in the muscles of females, before and after reproductive period, and somatic growth occurs significantly when the individual is not reproducing. Further detailed studies on ecological mechanisms influencing the success of the species, as the presence of competitors and preference for native preys, are needed to implement effective management measures aimed at preventing that the species proliferation in the environment is even more damaging to local biodiversity.

O balanço energético em espécies de peixes pode ser influenciado por variações sazonais no crescimento e ciclo reprodutivo, consumo de alimento e condições ambientais. O objetivo desta pesquisa foi o de avaliar as variações energéticas em uma espécie piscívora introduzida, Cichla kelberi, no alto rio Paraná, analisando as variações do teor calórico nos músculos, índice gonadossomático e o fator de condição entre subsistemas da planície de inundação, sexo e grau de maturação gonadal. Os resultados obtidos no presente estudo indicam que esta é uma espécie que converte eficientemente os recursos que obtém do ambiente. Embora apresentando maiores valores do fator de condição no ambiente onde foi registrada uma maior facilidade na obtenção de alimento (subsistema Paraná), o conteúdo energético identificado nos músculos da espécie foi o mesmo em ambos os subsistemas. Durante o processo de maturação gonadal verificou-se acúmulo de energia nos músculos de fêmeas, antes e após período reprodutivo, e crescimento somático ocorreu significativamente quando o indivíduo não estava se reproduzindo. Outros estudos, enfocando os mecanismos ecológicos que influenciam o sucesso das espécies, como a presença de competidores e a preferência por presas nativas, são necessários para implementar medidas destinadas a impedir uma maior proliferação da espécie no ambiente e que comprometa a biodiversidade local.

Key words: Condition factor, Energetic density, Gonadal maturation, Paraná and Baía Rivers.

\section{Introduction}

Knowledge of patterns of transference and energy transformation of a species is a key tool to understand its physiology and autoecology (Saldaña \& Venables, 1983). The allocation of assimilated energy for the different physiological functions (metabolism, somatic growth, and gonadal development) has important implications for the survival and reproductive success of fish (Wootton, 1990). This allocation may be influenced by seasonal changes, growth and reproductive cycle of fish, food consumption, and environmental conditions. Usually this influence modifies the caloric content of the tissues (Pandian \& Wivekanandam, 1985; Encina \& Granado-Lorencio, 1997; Benedito-Cecilio et $a l ., 2005)$. For this reason, the energy contents of somatic components may be good indicators of the physiological condition of a fish since they reflect environmental, physiological and nutritional factors (Cui \& Wootton, 1988).

Research studies related to the bioenergetics of fish are rare, especially about fresh water fish in their natural environment. In Brazil bionergetic studies have only been conducted in sea fish (Ngan et al., 1993). But in the last decades these studies have become more important especially in the upper Parana river basin (Doria \& Andrian, 1997;

${ }^{1}$ Cuidad Universitaria Paraje "El Pozo", Instituto Nacional de Limnología (CONICET-UNL), Santa Fe, C.P. 3000, Argentina. laespn@gmail.com

${ }^{2}$ Universidade Estadual de Maringá, Departamento de Biologia, Curso de Pós-Graduação em Ecologia de Ambientes Aquáticos Continentais, Nupelia, Av. Colombo, 5790, 87020-900 Maringá, Paraná, Brazil. 
Benedito-Cecilio \& Morimoto, 2002; Vismara et al., 2004; Dourado et al., 2005; Espínola et al., 2008, 2010). This paper, in addition to increasing the studies on the bioenergetics of fresh water fish from this region, it is the first one to study the calorimetric of an invasive species.

Currently, the introduction of non-native species is dealt as one of the major factors for biodiversity loss (Mack et al., 2000; Latini \& Petrere Júnior, 2004), being the second main reason of species extinction, after habitat destruction (Rodríguez, 2001).

The practice of introducing species as a stocking strategy was quite common until 1990 (Agostinho et al., 2007), and was mostly led by hydroelectric companies (Agostinho et al., 1994). For instance, Plagioscion squamosissimus (Heckel, 1840) (corvina) and species of Cichla Bloch \& Schneider, 1801 as C. kelberi Kullander \& Ferreira, 2006 and C. piquiti Kullander \& Ferreira, 2006 (peacock bass), native to the Amazon Basin were two of the main species that the companies introduced to the reservoirs of the rivers Grande, Tietê, and Paranaíba (Agostinho et al., 2005, 2007). These species have spread rapidly throughout the system (Kullander \& Ferreira, 2006), since the arrangement in cascade of the reservoirs increases the probability of dispersal of C. kelberi in neighboring reservoirs, including dam-free stretches of the river, e.g., in lakes of the upper Paraná River floodplain (Espínola, 2010).
In this way, an evaluation of energetic balance of Cichla kelberi, will provide a better comprehension of its ecology, since that evaluation expresses which proportion of energy consumed is directed to several life processes, and how this allocation may fluctuate during the life cycle of the species in the new habitat (Phan et al., 1993). This would let us know why invasive species such as Cichla kelberi become successful in the invaded environment.

Hence, the present study aims at evaluating differences in energy distribution during gonadal maturation in males and females; contributing with data to the general knowledge of the ecology of non native species like C. kelberi and developing an effective management aiming to reduce species negative effects on the Upper Paraná River floodplain.

\section{Material and Methods}

\section{Study area}

The upper Paraná River floodplain extends over the right margin of Paraná River ( $23^{\circ} 43^{\prime} \mathrm{S}$ to $25^{\circ} 33^{\prime} \mathrm{S}$ and $54^{\circ} 35$ to $53^{\circ} 10^{\prime} \mathrm{W}$ ), bordering the states of Mato Grosso do Sul and Paraná, within a stretch of river that is not dammed of $230 \mathrm{~km}$, located downstream from Porto Primavera Dam and upstream from Itaipu Reservoir (Fig. 1). This stretch is important both for the maintenance of fish diversity and for artisanal fisheries of the region (Agostinho et al., 2000).

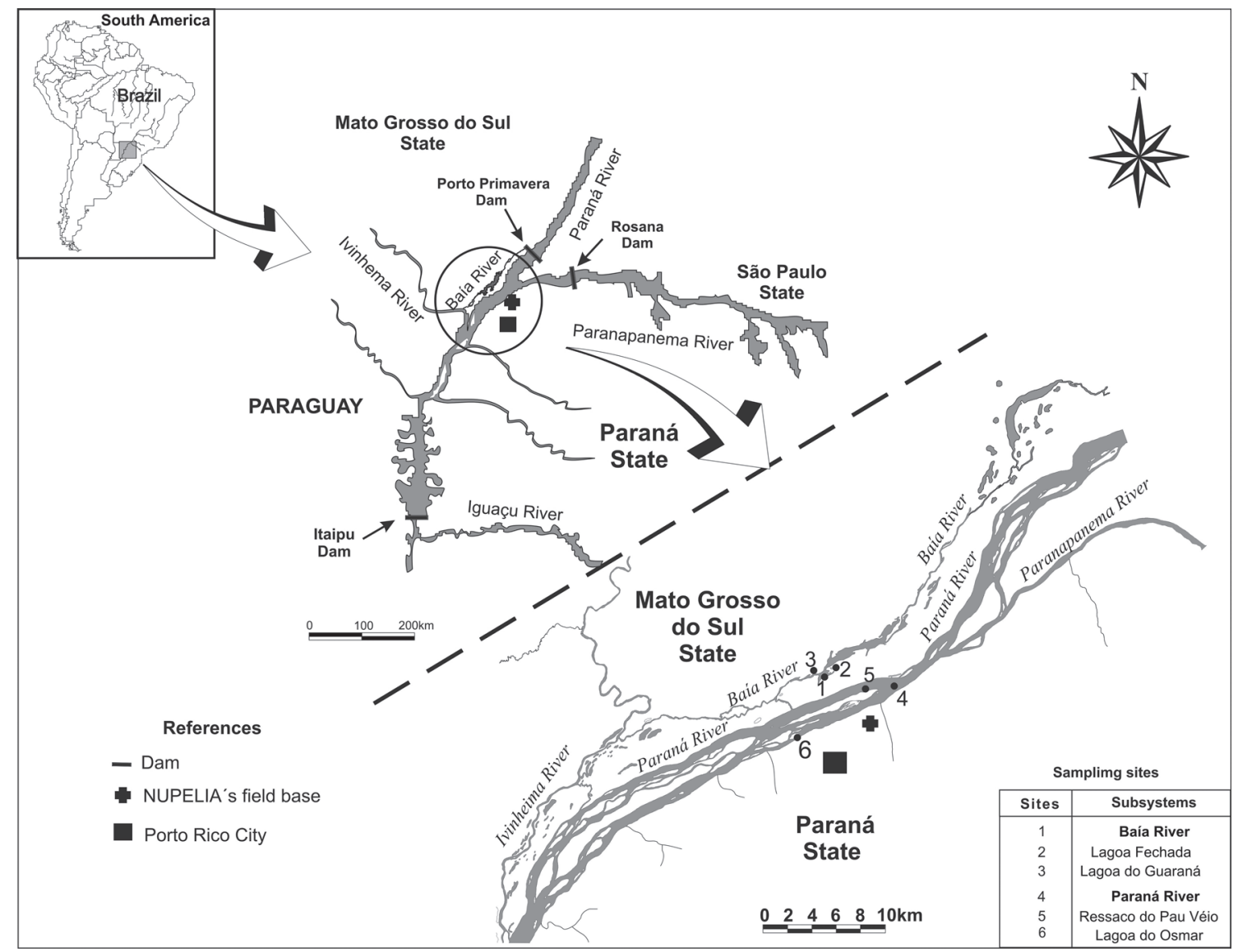

Fig. 1. Upper Paraná River floodplain, with emphasis on sampling points in each subsystem. 
Prior to 1998, when the filling of Porto Primavera Reservoir began, the hydrological regime of Paraná River was characterized by marked seasonal variation, with occurrence of pronounced floods (between November and May) and droughts (June to October). With the filling of the reservoir and start of operation of the hydroelectric power plant, the water level of Paraná River was drastically changed by the reduction in the intensity and duration of floods. Although irregular, the seasonal rainfall pattern is characterized by the onset of rains from October to April, and a dry season, from May to September (Agostinho et al., 2007).

\section{Variation of the hydrological regime}

Data about hydrological cycles of the study area were provided by the Department of Hydrology of Itaipu Binational, which were gathered in the hydrological stations located in Porto São José (Paraná State). The water level of Baía River was considered the same as the Paraná River, because although this river presents its own dynamics (Souza Filho \& Stevaux, 2004), we assumed that the variation in the hydrological regime of Baía River was similar to the Paraná due to the strong influence of the latter over the former. According to Fernandes et al. (2009), the quota of $4.51 \mathrm{~cm}$ was established, as benchmark of flood intensity that characterizes the flood levels.

During the study period, the upper Paraná River floodplain presented hydrometric levels not superior to the value previously established $(4.51 \mathrm{~m})$, unlike recorded in earlier periods (Fig. 2).

\section{Samplings}

The "Núcleo de Pesquisas em Limnologia, Ictiologia e Aquicultura" (NUPELIA), develops studies in the upper Paraná River floodplain since 1986. Thus, in the different projects implemented in the periods between 1986-1988

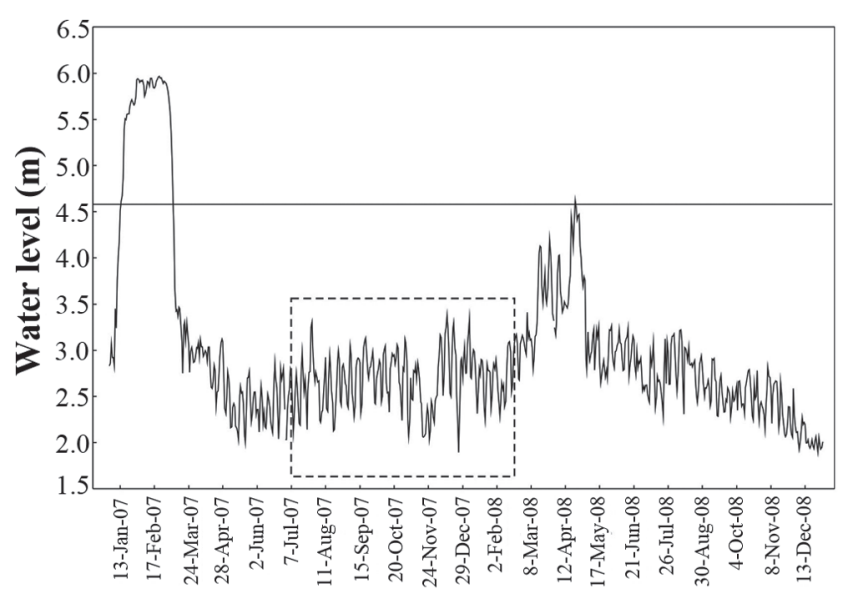

Date

Fig. 2. Daily variation in river levels during sampling period. Horizontal lines show the threshold of the water level for river bank overflow (4.51 m Paraná and Baía Rivers, Fernandes et al., 2009). The square notes the water level of the sampling period.
(FINEP); 1992-1995 (FUEM-PADCT-CIAMB) and 2000-2007 (PELD/CNPq) we gathered information of physical, chemical and biological components of the diverse aquatic habitats that make up the upper Paraná River floodplain (subsystems Ivinhema, Baía, and Paraná).

From this database we obtained the records of the captured individuals of Cichla kelberi Kullander \& Ferreira, 2006. Vouchers specimens are depositaded in Coleção Ictiológica do Nupélia, catalog numbers: NUP 12804 ( 1, 280,0 $\mathrm{mm} \mathrm{CP})$ and NUP 12806 (1, 185,0 mm CP).The studies encompassed quarterly samplings conducted between July 2007 to March 2008, in the subsystems Baía and Paraná, using gill nets with 2.4 to $16 \mathrm{~cm}$ between opposite knots. From each sampled individual, we determined the standard length $(\mathrm{cm})$ and total weight $(\mathrm{g})$. The development of the gonads was macroscopically determined, considering macroscopic characteristics related to color, transparency, superficial vascularization, flaccidity, size, and position in the abdominal cavity. For this, we used the scale of gonadal maturation proposed and described by Vazzoler (1996), based in the extension of the gonad in relation to the body cavity, shape, colour, consistency, and constituted by the following maturation stages: $\mathrm{A}=$ immature, $\mathrm{B}=$ resting, $\mathrm{C}=$ maturing, $\mathrm{D}=$ mature, $\mathrm{E}=$ spent.

From each exemplar we extracted muscle samples from the base of the dorsal fin, for both sexes and at each gonadal maturation stage (Benedito-Cecilio et al., 2005; Espínola et al., 2010). All the samples were preserved in ice and taken to the laboratory of Energetic Ecology of NUPELIA, where they were processed. Each sample was rinsed in distilled water and dried at $60^{\circ} \mathrm{C}$ in forced ventilation oven to constant weight. The dried muscles were ground in ball mill to obtain a fine powder. The caloric value of the sample (cal-g-1 dry weight) was determined by bomb calorimetry (PARR 1261).

\section{Data analysis}

After graphical inspection of the means and standard deviation of the values of caloric content of the muscles, GSI, and condition factor for both sexes and stage of gonadal maturation, we employed a two-factor ANOVA to determine significant differences, and post-hoc Fisher's test. In order to determine the effect of gonadal maturation on the body weight, we calculated the gonadosomatic index $(\mathrm{GSI})$, where GSI $=$ (weight of gonads / total weight*100 (Vazzoler, 1996).

The condition factor was estimated according to the expression: $\mathrm{K}=\left(\text { total weight } / \text { standard length }^{\mathrm{b}}\right)^{*} 1000$ (Vazzoler, 1996). The parameter "b" was obtained for both sexes, by means of the regression between the standard length and total weight.

Whenever we could not achieve the assumptions of normality and homoscedasticity, we used the non-parametric Kruskal-Wallis test. The relationship between standard length and caloric content was examined using the Pearson correlation coefficient. In this analysis there was normality 
and homoscedastic. The significance level adopted for all analyses was $p<0.05$. All the statistical analyses were made using the software STATISTICA 7.1 ${ }^{\mathrm{TM}}$ (Statsoft, 2005).

\section{Results}

We analyzed 110 specimens of Cichla kelberi, 43 males and 57 females. No significant differences were found in caloric content between females $(\mathrm{F}=0.02, \mathrm{p}=0.89)$ and males $(\mathrm{F}=$ $0.51, \mathrm{p}=0.47$ ) of Baía and Paraná subsystems. Thus, for the following analyses, data were processed together.

Significant differences between sexes, with respect to caloric content, were also not detected $(\mathrm{F}=0.03, \mathrm{p}=0.85)$, but the male values were slightly higher than the female values. In the interaction between the sexes and the stages of gonadal maturation, we did not find significant differences $(\mathrm{F}=1.53 \mathrm{p}$ $=0.19$ ). However, mean values significantly different were verified when analyzing caloric values from each sex, at different stages $(\mathrm{F}=20.94, \mathrm{p}=0.0001)$ (Fig. 3 ).

Both sexes presented increase in caloric content during gonadal development; nevertheless the females had higher values than males, which remained with greater values at stages spent and rest.

The gonadosomatic index (GSI) values were higher for females during all gonadal maturation stages, with greater variability in the stages maturation and spent (Fig. 4a). Through linear regression analysis, performed between caloric content and GSI, both females $\left(r^{2}=0.43, p=0.003\right)$ and males $\left(r^{2}=0.68, p=0.0000005\right)$, presented a positive correlation (Fig $4 b)$. Significant correlation between caloric values and stages of gonadal maturation were found only for females at rest $(\mathrm{r}=$ $-0.827, \mathrm{p}=0.0422$ ).

The correlation between caloric content and standard length, for females $(r=0.55, p=0.000001)$ and males $(r=0.60$; $p=0.0002)$ was positive. The females presented growth slightly higher than that of males (Fig. 5). For the males, we

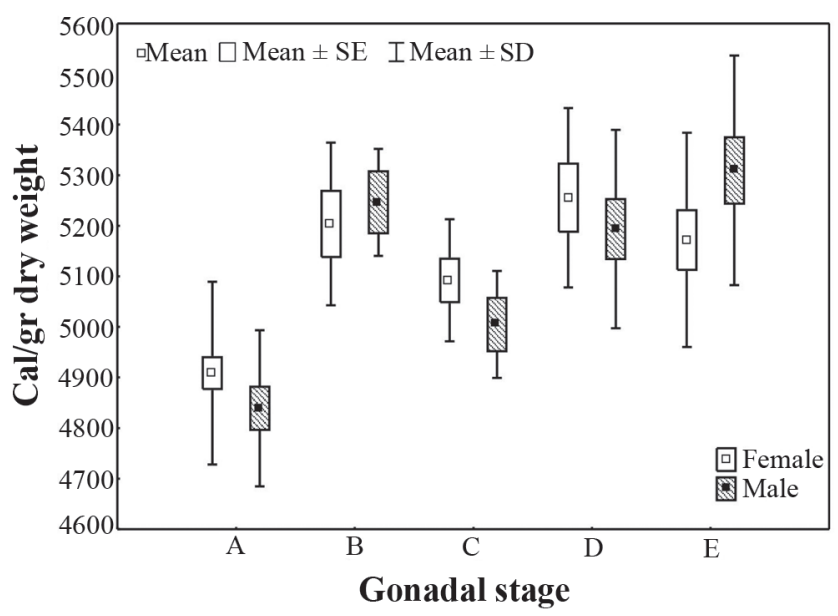

Fig. 3. Caloric mean values for the maturity stages $(A=$ immature, $\mathrm{B}=$ resting, $\mathrm{C}=$ maturing, $\mathrm{D}=$ mature, $\mathrm{E}=$ spent) of males and females of $C$. kelberi, sampled in the upper Paraná River floodplain. did not observe significant regressions, while for females, only the stage immature presented significant regression $(r=$ $0.5225, \mathrm{p}=0.0018$ ).

The parameters of the regression total weight $\mathrm{x}$ standard length, for females and males, belonging to Baía subsystem were: $\mathrm{a}=-4.65, \mathrm{~b}=3.31, \mathrm{r}^{2}=0.98 ; \mathrm{a}=-5.51, \mathrm{~b}=3.46, \mathrm{r}^{2}=0.96$, whereas for females and males of Paraná subsystem were: a $=-4.35, \mathrm{~b}=3.18, \mathrm{r}^{2}=0.96 ; \mathrm{a}=-4.03, \mathrm{~b}=3.09, \mathrm{r}^{2}=0.98$, respectively. The values of the condition factor of individuals sampled in Paraná subsystem were superior to those observed for Baía. Essentially the values of the condition factor of individuals from Paraná subsystem were synchronized with hydrometric level. For the Baía subsystem, the condition factor remained with values little variable throughout the period, except at the end of the period when the condition factor decreased, occurring the same with the hydrometric level.

The ANOVA two factor between caloric content, sex and subsystem didn't show a significant difference $(F=0.33, p=$ $0.56)$. On the other hand, this same analysis showed significant differences in interaction of the values of condition factor for the analysis between sex and subsystem $(\mathrm{F}=125.17, \mathrm{p}=$ 0.0001 ; Fig. 6a). Males and females of Paraná subsystem presented higher mean values of condition factor in comparison to individuals sampled in Baía subsystem. On the other hand, for this latter biotope, the males presented lower condition factor than females (Fig. 6b).

In the distribution of the values of the condition factor $(\mathrm{K})$ of males and females, for the gonadal maturation stages, we registered that the males of Paraná subsystem had higher values than those observed for females. The values of $\mathrm{K}$ were greater for males and females at rest than for those individuals at maturation stage. Otherwise, for Baía subsystem, the females presented the highest values.

Considering the two examined subsystems, for males, we could not establish any pattern, unlike the females, for which we observed increase in the values of 1.3 until maturity stage, reducing then for the individuals from both analyzed biotopes.

\section{Discussion}

Meantime, we did not observe significant difference between energy density of males and females of $C$. kelberi sampled in the subsystems Baía and Paraná, despite the intense construction of dams in the upper Paraná River basin (Agostinho et al., 2007). The values of caloric content, for each sex, regardless the gonadal maturation stage, did not present significant differences. Nevertheless in the assessment per gonadal maturation stage, we verified that the caloric content of females was slightly higher than the recorded for males. Thus, caloric changes in the muscles of males and females, during the gonadal maturation, indicate that there is an effect of reproduction on the caloric content of the species.

Individuals at spent stage presented the highest values of caloric content among males. According to Jepsen et al. (1999) this may be due to the dimorphic characteristic of the species during reproductive season, since the males present 

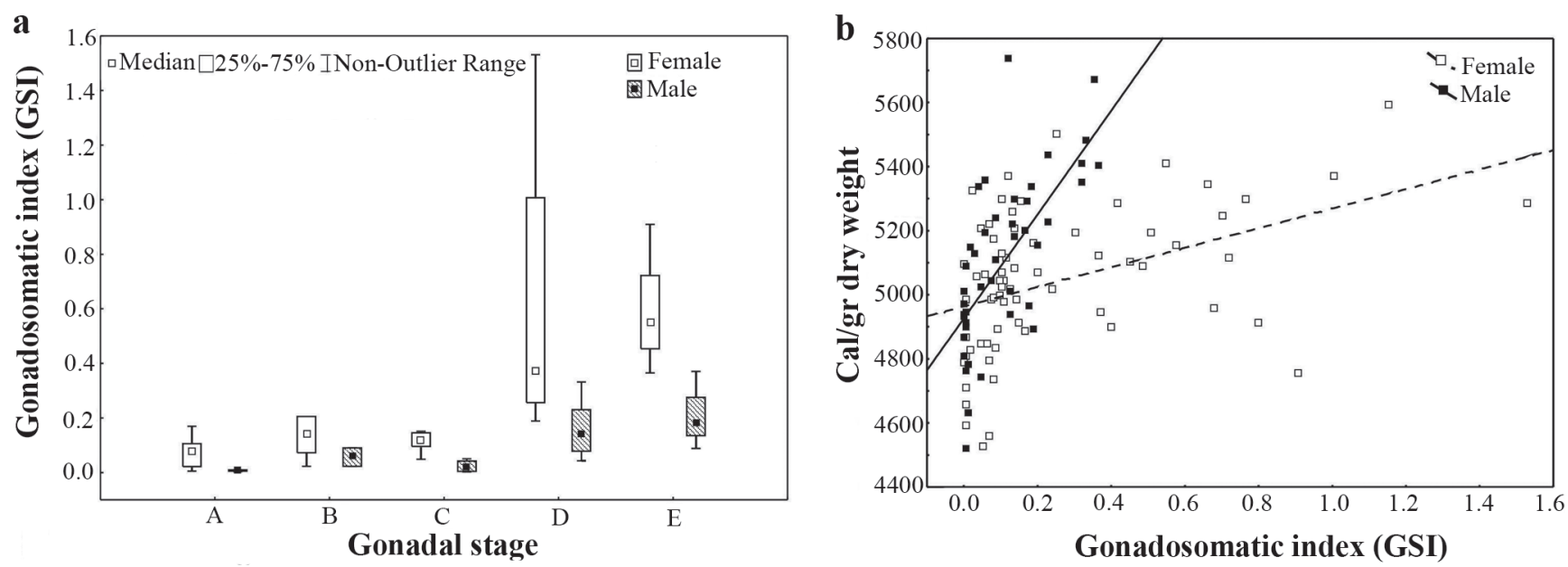

Fig. 4. (a) Gonadosomatic index (GSI), mean values of the gonadosomatic index, per gonadal maturation stage; (b) Correlation between caloric content and gonadosomatic index. Gonadal maturation stages: $\mathrm{A}=$ immature, $\mathrm{B}=$ resting, $\mathrm{C}=$ maturing, $\mathrm{D}=$ mature, $\mathrm{E}=$ spent.

a fat deposit in occipital region. In response to ecological conditions, most species of the genus Cichla develops with a remarkable degree of phenotypic plasticity, able to modify the reproductive tactics (period of spawning, fecundity, type of spawning, and length at first maturity). These characteristics were highlighted by several authors (Fontenele, 1950; Zaret, 1980; Jepsen et al., 1999; Gomiero \& Braga, 2004) and they allow the adaptation of specie to altered environments, natural or artificial (Espínola, 2005), that result to production of the maximum number of young that achieve to maturity (Potts \& Wootton, 1984).

Therefore, like most species of the genus Cichla, C. kelberi exhibits parental care, provided by both sexes (Goodwin et al., 1998). During this period, adults stop feeding and devote exclusively to the care of the offspring (Fontenele, 1950; Braga, 1952; Zaret, 1980). Because is a short distance migratory fish (Agostinho et al., 1994), the high energy investment to adult individuals is probably related to care and protection of offspring (Jepsen et al., 1999).

The results emphasized the variation in gonad weight, in relation to body weight of females, with the highest values of GSI in the phases close to the reproduction (maturation) and post-reproduction (spent), reflecting in an increase of volume and weight of ovaries and testes.

The values of caloric content were correlated positively and significantly with the values of GSI and standard length in both sexes. In the linear regression analysis performed between GSI and the standard length and the caloric content, distributed by gonadal maturation stages in both sexes, we detected correlation only for females at stages rest and immature. This fact indicates that the gonadal maturation is a process that requires high energy demand of males and females, not being associated with somatic investment that the species performs at adult stage.

The relationship between the caloric content, condition factor and environment, emphasizes the importance of improving the knowledge on how these variables interact with the environment, as well as on what effects and biological consequences they would bring for the somatic growth, reproductive success and, in this particular case, for the establishment of a new environment. For instance, the fact that there were no significant differences between the caloric content and the sex in relation to the environment, would show that the first two variables don't change according to the environment, but they do vary according to the gonadal maturity level and/or reproductive activity, as shown in Figure 3.

Meanwhile, the significant difference found between the condition factor and the environment and sex, could be showing that both environment and sex influence in the

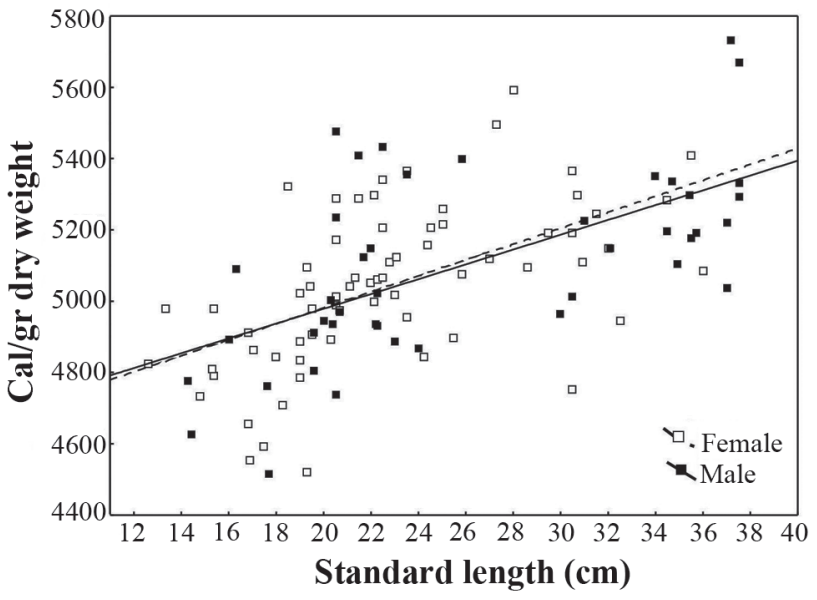

Fig. 5. Correlation between standard length and caloric content of females and males. Gonadal maturation stages: $\mathrm{A}=$ immature, $\mathrm{B}=$ resting, $\mathrm{C}=$ maturing, $\mathrm{D}=$ mature, $\mathrm{E}=$ spent. 

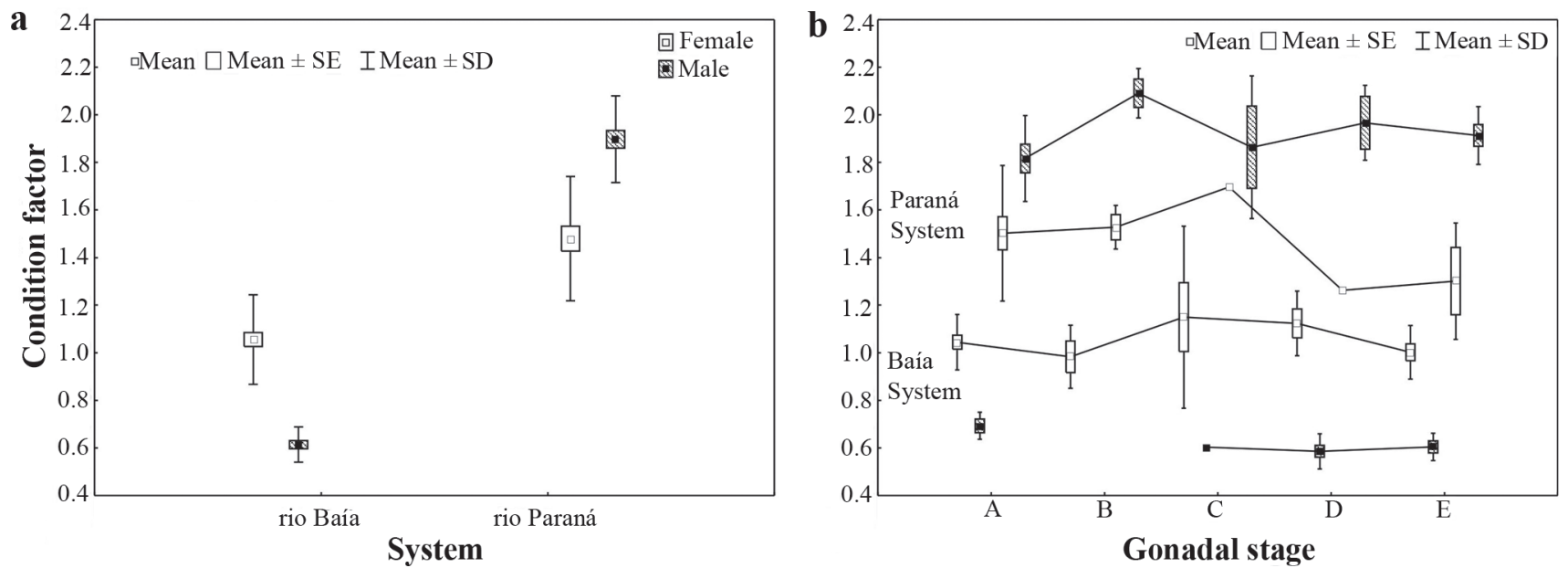

Fig. 6. Monthly variations in the values of condition factor for both sexes. (a) Condition factor in the different systems; (b) different system and different gonadal development. Gonadal maturation stages: $\mathrm{A}=$ immature, $\mathrm{B}=$ resting, $\mathrm{C}=$ maturing, $\mathrm{D}=$ mature, $\mathrm{E}=$ spent.

variation of the condition factor due to the food quality available in the environment and the gonadal maturity level present in the individual, besides other abiotic and/or biotic variables that could be influencing the somatic production and/or the metabolism, as suggested Tytler \& Calow (1985).

The high levels of factor condition found in the Paraná subsystem could be due to the fact that during the sampling period of the present study, there was a little increase in water level, but without reaching the threshold of the water level for river bank overflow $(4.51 \mathrm{~m})$ in both subsystems. The increase in water level observed for the period coincided with the increase of condition factor for the individuals collected in Paraná River. This fact may have been promoted by the increase in water transparency, facilitating the capture of preys with better nutritional value (Abujanra et al., 2009).

For the Baía subsystem, the condition factor was always lower than that of Paraná, and the increase in the water level seems to have not influenced the increase in the condition factor, but rather, its reduction. One of the alleged motives for the reduction of the condition factor in this system is the increase of transparency due to the decrease of the fine sediment caused by Puerto Primavera Dam, making it more difficult the possibility of capturing better quality food resources.

Years with an incipient or even no peak of flood resulted in mean values of body condition far superior to those years with large floods, especially in habitats most affected by the closure of Porto Primavera Dam, such as the Paraná River (Abujanra et al., 2009).

According to Espínola (2009), these subsystems present different population densities and the record of the species was initially for Paraná subsystem in 1992, and only in 2000, in Baía subsystem. This period corresponds to a short time interval for the species to adopt different life history traits at each subsystem, as suggested by Neat et al. (2003). On the other hand, in Venezuela, the hypothesis that Cichla species from different subsystems (river, lake, and reservoir) have different condition factors (Jepsen et al., 1999) was not yet corroborated. The result of this study revealed a first indication that the condition factor may differ between subsystems, opposed to what we observe with the caloric content.

Males presented higher condition factor than females in Paraná subsystem, however in Baía, the females had highest condition factor. The difference between gonadal maturation stages, for each sex, in the different subsystems is expected, and may be influenced by different environmental variables, such as fluctuations in oxygen levels and water transparency, or even by prey availability (Abujanra et al., 2009).

Most species in this region are not migratory and, like $C$. kelberi, they do not migrate to meet reproductive cycle. The fat deposits in the tissue and consequent caloric increase are used for rapid growth and efficient reproduction, allowing the reproduction with only $16.5 \mathrm{~cm}$ standard length (Suzuki \& Agostinho, 2001) and with one year age (Braga, 1952; Novoa, 1996). The results obtained in the present study permit assuring that this is a species that efficiently converts the resources of the environment into energy. Although presenting higher condition factor in the environment where there is a greater ease in getting food (Paraná subsystem), the energy identified in the muscles was the same in both subsystems. During the process of gonadal maturation there is optimization in energy accumulation in the muscles of females, before and after reproductive period, and somatic growth occurs significantly when the individual is not reproducing. Further detailed studies on ecological mechanisms influencing the success of the species, as the presence of competitors and preference for native preys, are needed to implement effective management measures aimed at preventing that the species proliferation in the environment is even more damaging to local biodiversity. 


\section{Acknowledgements}

We would like to acknowledge the Núcleo de Pesquisa em Limnologia, Ictiologia e Aquicultura (Nupelia, UEM, Brazil) and its several researchers and students that have been working since the 80 's to assemble the long term data set used in this study. This work benefited from funding by CNPq (PELD Programme 2000-2007); CNPq (2006-2), CAPES scholarship (to LAE), FUEM-PADCT-CIAMB (1992-1995) and FINEP (1986-1988).

\section{Literature Cited}

Abujanra, F., A. A. Agostinho \& N. S. Hahn. 2009. Effects of the flood regime on the body condition of fish of different trophic guilds, in the Upper Paraná River floodplain, Brazil. Brazilian Journal of Biology, 69: 469-479.

Agostinho, A. A., L. C. Gomes \& F. M. Pelicice. 2007. Ecologia e Manejo de Recursos Pesqueiros em Reservatórios do Brasil. Maringá, EDUEM, 501p.

Agostinho, A. A., H. F. Júlio Júnior \& J. M. Petrere. 1994. Itaipu reservoir (Brazil): impacts of the impoundment on the fish fauna and fisheries. Pp. 171-184. In: Cowx, I. G. (Ed.). Rehabilitation of Freshwater Fisheries. Bodman, Fishing News Books, 496p.

Agostinho, A. A., S. M. Thomaz \& L. C. Gomes. 2005. Conservation of the biodiversity of Brazil's inland waters. Conservation Biology, 3: 646-652.

Agostinho, A. A., S. M. Thomaz, C. V. Minte-Vera \& K. O. Winemiller. 2000. Biodiversity in the high Paraná River floodplain. Pp. 89-118. In: Gopal, B., W. J. Junk \& B. Davis (Eds.). Biodiversity in wetlands: assessment, function and conservation. Leiden, Backhuys Publishers, 353p.

Benedito-Cecilio, E. \& M. Morimoto. 2002. Effect of preservatives on caloric density in the muscles of Hoplias aff. malabaricus (Bloch, 1794) (Osteichthyes, Erythrinidae). Acta Scientiarum, 2: 489-492.

Benedito-Cecilio, E., A. L. Pereira, A. C. A. Faria \& H. Baleroni. 2005. Effects of habitat on physiological indicators in Leporinus friderici (Pisces, Anostomidae) in the influence area of the Corumbá reservoir, Goiás, Brazil. Acta Limnologica Brasiliensia, 17: 71-79.

Braga, R. 1952. Ninhos de tucunarés Cichla temensis e Cichla ocellaris. Revista Brasileira de Biologia, 12: 273-278.

Cui, Y. \& R. J. Wootton. 1988. Effects of ration, temperature and body size on the body composition, energy content and condition of minow, Phoximus phoximus (L). Journal of Fish Biology, 32: 749-764.

Doria, C. R. C. \& I. F. Andrian. 1997. Variation in energy content of somatic and reproductive, tissues related to the reproductive cycle and feeding of female Pimelodus maculatus Lacépède, 1803 (Siluriformes, Pimelodidae) and Schizodon borellii Boulenger, 1895 (Characiformes, Anostomidae). Revista Unimar, 2: 421-437.

Dourado, E. C. S., E. Benedito-Cecilio \& J. D. Latini. 2005. O grau de trofia do ambiente influencia a quantidade de energia dos peixes? Pp. 211-222. In: Rodrigues, L., S. M. Thomaz, A. A. Agostinho \& L. C. Gomes (Eds.). Biocenoses em reservatórios. Padrões espaciais e temporais. São Carlos, Rima, 321p.

Encina, L. \& C. Granado-Lorencio. 1997. Seasonal variations in the physiological status and energy content of somatic and reproductive tissues of chub. Journal of Fish Biology, 50: 511-522.
Espínola, L. A. 2005. Táctica reprodutiva e estrutura da população Cichla kelberi Kullander \&Ferreira, 2006 (Perciformes, Cichlidae) em ambientes com diferentes regimes hidrológicos. Unpublished MSc. Dissertation, Universidade Estadual de Maringá, Maringá, 45p.

Espínola, L. A. 2009. Cichla kelberi, Kullander \& Ferreira, 2006, um piscívoro introduzido na Planície de inundação do alto rio Paraná: aplicação do modelo INVASS. Unpublished Ph.D. Dissertation, Universidade Estadual de Maringá, Maringá, 65p.

Espínola, L. A., C. V. Minte-Vera \& H. F. Júlio Júnior. 2010. Invasibility of reservoirs in the Paraná Basin, Brazil, to Cichla kelberi Kullander and Ferreira, 2006. Biological Invasions, 12: 1837-1888.

Espínola, L. A., W. M. Domingues \& E. Benedito. 2008. Variaciones en el contenido de energía en músculos de Salminus brasiliensis en diferentes estados de desenvolvimiento gonadal en el área de influencia del reservatório de Manso, Mato Grosso, Brasil. Iheringia, Série Zoologia, 98: 1-5.

Fernandes, R., A. A. Agostinho, E. A. Ferreira, C. S. Pavanelli, H. I. Suzuki, D. P. Lima \& L. C. Gomes. 2009. Effects of the hydrological regime on the ichthyofauna of riverine environments of the Upper Paraná River floodplain. Brazilian Journal of Biology, 69: 669-680.

Fontenele, O. 1950. Contribuição para o conhecimento da biologia dos tucunarés (Actinopterygii, Cichlidae). Aparelho de reprodução, hábitos de desova e incubação. Revista Brasileira de Biologia, 10: 503-519.

Gomiero, L. M. \& F. M. S. Braga. 2004. Reproduction of species of the genus Cichla in a reservoir in southeastern Brazil. Brazilian Journal of Biology, 64: 613-624.

Goodwin, N. B., S. Balshine-Earn \& J. D. Reynolds. 1998. Evolutionary transitions in parental care in cichlid fish. Proceedings Royal Society London B, 265: 2265-2272.

Jepsen, D. B., K. O. Winemiller, D. C. Taphorn \& D. R. Olarte. 1999. Age structure and growth of peacock cichlids from rivers and reservoirs of Venezuela. Journal of Fish Biology, 55: 433-450.

Kullander, S. O. \& E. J. G. Ferreira. 2006. A review of the South American cichlid genus Cichla, with descriptions of nine new species (Teleostei: Cichlidae). Ichthyological Exploration of Freshwaters, 17: 289-398.

Latini, A. O. \& M. Petrere Júnior. 2004. Reduction of a native fish fauna by alien species: an example of Brazilian tropical freshwater lakes. Fisheries Management and Ecology, 11: 71-79.

Mack, R. N., D. Simberloff, W. M. Lonsdale, H. Evans, M. Clout \& F. A. Bazzaz. 2000. Biotic invasions: causes, epidemiology, global consequences, and control. Ecological Applications, 10: 689-710.

Neat, F. C., W. Lengkeek, E. P. Westerbeek, B. Laarhoven \& J. J. Videler. 2003. Behavioural and morphological differences between lake and river populations of Salaria fluviatilis. Journal of Fish Biology, 63: 374-387.

Ngan, P. V., V. Gomes, D. M. Morais \& M. J. A. C. R. Passos. 1993. Estudo bioenergético de animais marinhos costeiros. Instituto Oceanográfico, 10: 199-215.

Novoa, D. F. R. 1996. Aspectos generales sobre la biología, pesquería, manejo y cultivo del pavón (Cichla orinocensis y Cichla temensis) en el lago de Guri y otras áreas de la región Guayana. Natura Caracas, 96: 34-39.

Pandian, T. J. \& E. Wivekanandam. 1985. Energetics of feeding and digestion. Pp. 99-124. In: Tyler, P. \& P. Calow (Eds.). Fish energetics: new perspectives. London, Croom Helm, 349p.

Phan, V. N., V. Gomes, D. M. Morais \& M. J. A. C. R. Passos. 1993. Estudo bioenergético de animais marinhos costeiros. I. 
Paralonchurus brasiliensis (Perciformes, Sciaenidae) Boletim do Instituto Oceanográfico, 10: 199-215.

Potts, G. W. \& R. J. Wootton (Eds.). 1984. Fish Reproduction: Strategies and Tactics. London, Academic Press, 410p.

Rodríguez, J. P. 2001. Exotic species introductions into South America: an underestimated threat? Biodiversity and Conservation, 10: 1983-1996.

Saldaña, J. \& B. Venables. 1983. Energy compartmentalization in a migratory fish, Prochilodus marie (Prochilodontidae), of the Orinoco river. Copeia, 1983: 617-623.

Souza Filho, E. R. \& J. C. Stevaux. 2004. Geology and geomorphology of the Baia-Curutuba River Complex. Pp. 129. In: Thomaz, S. M., A. A. Agostinho \& N. S. Hahn (Eds.). The upper Paraná River and its floodplain: physical aspects, ecology and conservation. Leiden, Backhuys Publishers, 393p.

StatSoft. 2005. Statistica (data analysis software system), ver. 7.1. StatSoft, Inc. www. statsoft.com.

Suzuki, H. I. \& A. A. Agostinho. 2001. Reprodução de peixes do reservatório Corumbá (GO). Pp. 227-323. In: Agostinho, A. A., R. Fugi, S. Veríssimo \& J. D. Latini (Eds.). Estudos Ictiológicos na Área de Influência do AHE de Corumbá. Relatório final. Maringá, EDUEM, 350p.
Tytler, P. \& P. Calow. 1985. Fish Energetics: new perspectives. Sydney, Croom Helm, 349p.

Vazzoler, A. E. A. M. \& N. A. Menezes. 1992. Síntese de conhecimentos sobre o comportamento reprodutivo dos Characiformes da América do Sul (Teleostei, Ostariophysi). Revista Brasileira de Biologia, 4: 627-640.

Vismara, M. R., E. Benedito-Cecilio \& A. C. A. Faria. 2004. Efeito da maturação gonadal sobre o conteúdo calórico e condição geral de peixes da planície de inundação do alto rio Paraná. Acta Scientiarum, 2: 189-199.

Wootton, R. J. 1990. Ecology of Teleost Fishes. London, Chapman and Hall, 404p.

Zaret, T. M. 1980. Life history and growth relationships of Cichla ocellaris, a predatory South American cichlid. Biotropica, 12: 144-157.

Submitted April 1, 2011

Resubmitted February 14, 2012

Accepted March 9, 2012

Published June 29, 2012 